\title{
EXCESS OF PAPPENHEIMER BODIES (SIDEROCYTES) IN TWO SPLENECTOMIZED SIBLINGS WITH CONGENITAL DYSERYTHROPOIETIC ANEMIA - TYPE II (CDA-II) AND IRON OVERLOAD
}

\author{
Ladislav Chrobák, Jindriška Matysová
}

Charles University in Prague, Faculty of Medicine and University Hospital in Hradec Králové: $2^{\text {nd }}$ Department of Medicine, Division of Clinical Hematology

Summary: In two splenectomized siblings with congenital dyserythropoietic anemia type -II (CDA-II) and iron overload excess of Pappenheimer bodies reaching 46, $4 \%$ and 15,9\% respectively was found. Cause, significance and differential diagnosis of this finding were discussed.

Key words: CDA-II; Splenectomy; Iron overload; Pappenheimer bodies

Excess of Pappenheimer bodies (siderocytes) has been found in two splenectomized siblings with CDA-II.

Pappenheimer bodies were first time described in 1945 by Alwin M. Pappenheimer in three patients after splenectomy because of hemolytic anemia of undetermined cause (12). Pappenheimer stressed that these bodies appeared only after splenectomy although morphological characteristics suggested a relationship to certain intraerythrocytic parasites. The author has not obtained any conclusive proof of their parasitic nature. The inclusions gave positive Perl's reaction. He considered the possibility that these iron containing bodies might be identical with the iron containing bodies described in 1941 by Grüneberg (3). According to our knowledge it is the first description of Pappenheimer bodies in CDA-II.

\section{Patient Reports}

In two siblings at the age of 20 (K. J.) and 5 years (K. K.) diagnosis of CDA-II has been made 30 years ago (7).

The diagnosis of CDA-II was established:

By the demonstration of erythroid hyperplasia, karyorrhexis and erythroblastic bi- and multinuclearity in the bone marrow.

By positive results of the acidified serum tests but negative results with patient's own serum.

By demonstration of typical ultrastructural features of erythroblasts and some erythrocytes showing the "double membrane phenomenon".

The study of survival of erythrocytes with ${ }^{51} \mathrm{Cr}$ revieled shortened survival with destruction in the spleen. The liver biopsy performed during operation demonstrated iron overload. Both siblings were splenectomized at the age of 23 (K. J.) and 15 years (K. K.) respectively to diminishe the iron overload due to hemolysis in addition to the ineffective erythropoiesis (7). Iron overload is a frequent complication in CDA-II $(4,6)$. Splenectomy led to moderate increase in hemoglobin, increase or nearly normalization of the red cell survival but did not prevent further iron loading. In 2004 the serum ferritin reached in K. J. 1450,4 $\mu \mathrm{g} / 1$ and in K. K. $1131,7 \mu \mathrm{g} / 1$ (normal value $30-350 \mu \mathrm{g} / 1$ ), liver biopsy revieled excessive iron overload in both patients with che-

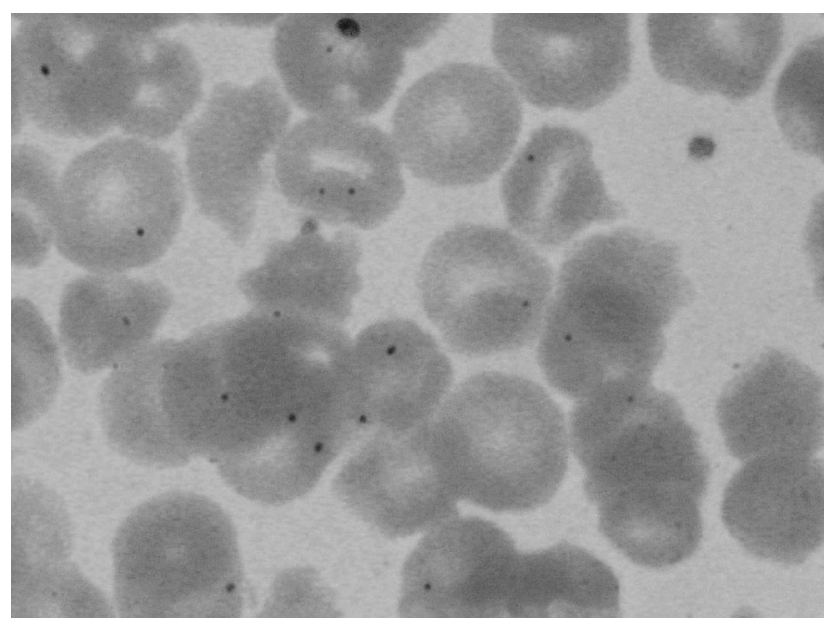

Fig. 1: Pappenheimer bodies in patient K. J. In one erythrocyte Pappenheimer body and Howell-Jolly body are present. 
mically determined liver iron concentration $14843 \mu \mathrm{g} / \mathrm{g}$ and $15415 \mu \mathrm{g} / \mathrm{g}$ respectively (normal value $70-1400 \mu \mathrm{g} / \mathrm{g}$ ).

The blood films reported at that time in K. J. and K. K. have shown 46,4 \% and 15,9\% of Pappenheimer bodies respectively (Fig. 1). The iron stain confirmed that the Pappenheimer bodies were siderocytes.

\section{Discussion}

Pappenheimer bodies are siderosomes (iron-containing granules with positive Perl's stain). Electron microscopy of these bodies shows that the iron is often contained within a lysosome as confirmed by the presence of acid phosphate. Siderosomes may also contain degenerating mitochondria, ribosomes, and other cellular remnants (6). Using iron stain we observed that siderocytes bodies were formed by 1 to 3 , occasionally even by more particles. Basophilic stippling represents dispersed blue granulation. HowellJolly bodies are spherical in shape, usually not larger than $0,5 \mu \mathrm{m}$ in diameter and give a positive Feulgen reaction for DNA.

Pappenheimer bodies can be mistaken for Babesia (2). Human babesiosis is an acute febrile illness sometimes complicated by hemolytic anemia common in North America. The illness is caused by intraerythrocytic protozoal parasites of the genus Babesia. Babesia organism measures $0,9-2 \mu \mathrm{m}$, Pappenheimer bodies are up to $2 \mu \mathrm{m}$ in size.

Spuriously elevated platelet counts counted by an electrooptical counter due to Pappenheimer bodies have been reported too $(11,13)$.

Kent has shown that siderocytes are not present in normal erythropoiesis with intact spleen. In hematologic disturbances with reticulocytosis and intact spleen the observed counts were $0,10-1,11 \%$, in splenectomized persons because of traumatic rupture of the spleen $0,20-0,40 \%$. In splenectomized patients with persistent hematologic disturbance the counts varied from $0,9 \%$ to $57 \%$ in a case of hemoglobin C disease with splenectomy (9).

Pappenheimer bodies were also observed in congenital sideroblastic anemias $(5,14)$. Iwaha et al. (8) reported a case of macrocytic anemia in a 75-year-old alcohol abuser who suffered vitamin $B_{6}$ deficiency. Abstention of alcohol led to the disappearance of Pappenheimer bodies commonly observed in the red blood cells of drinkers. Mende and Fülle (10) mentioned a 36-year-old alcohol abuser with hemolytic anemia (Zieve-syndrom) with $25 \%$ of Pappenheimer bodies in admission with their complete disappearance after 20 days of abstention of alcohol.

In our two patients the presence of Pappenheimer bodies was due to the CDA-II and the splenectomy. How much the iron overload contributed will be possible to be assessed after normalization of serum ferritin levels.

\section{References}

1. Bull BS, Breton-Gorius J. Morphology of the erythron. $5^{\text {th }}$ Ed. Williams Hematology, Beutler E. et al. Mc Graw-Hill, 1995:49-63.

2. Carr JM, Emery S, Stone BF et al. Babesiosis. Diagnostic Pitfalls. Am J Clin Pathol 1991;95:774-7.

3. Grüeberg M. Siderocytes: a new king of erythrocytes. Nature (Lond.) 1941;148:114-5.

4. Heimpell H, Anselstetter V, Chrobák L et al. Congenital dyserythropoietic anemia type II: epidemiology, clinical appearance, and prognosis based on long-term observation. Blood 2003;102:4576-81.

5. Hellier KD, Hatchwelle E, Ducombe AS. X-linked sideroblastic anaemia with ataxia: another mitochondrial disease. J. Neurol. -Neurosurg. Psychiatry 2001; 70(1):65-9.

6. Howinga, JA, Solenthaler M, Dufour JF. Congenital dyserythropoietic anaemia type II (HEMPAS) and haemochromatosis: a report of two cases. Eur J Gastroenterol Hepatol 2003;15:1141-7.

7. Chrobák L, Radochová D, Smetana K et al. Congenital dyserythropoietic anaemia, type II (HEMPAS) in three siblings. Folia Haematol. (Leipzig) 1980; 107:628-40.

8. Iwama $\mathrm{H}$, Iwase $\mathrm{O}$, Hayashi $\mathrm{S}$ et al. Macrocytic anemia with anisocytosis due to alcohol abuse and with B6 deficiency. Jap J Clin Hematol 1998;39(11):1127-30.

9. Kent G, Minick OT, Volini FI et al. Autophagic vacuoles in human red cells. Am J Pathol 1966;48:831-9.

10. Mende S. Fülle HH. Pappenheimer-Körperchen: Erythrozyten Einschlüsse bei hämolytischer Anämie. Med Welt 1979;30:372-4.

11. Morton BD, Orringer EP, Lahart LA. Pappenheimer bodies. An additional cause for a spurious platelet count. Am J Clin Pathol 1980;74:310-1.

12. Papenheimer AM, Thompson WP, Parker DD et al. Anaemia associated with unidentified erythrocytic inclusions after splenectomy. Q J Med 1945;38:75-100.

13. Wilson EC, Geddie AA, Orringer EP et al. Pappenheimer bodies and spuriously elevated platelet counts. J Amer Med Ass 1981;246:938.

14. Zarco MA, Felin E, Rozman C et al. Ultrastructural study of erythrocytes containing Pappenheimer bodies in a case of congenital sideroblastic anaemia (CSA). Br J Haematol. 1991;78:577-8.

Submitted April 2004.

Accepted June 2004.

Prof. MUDr. Ladislav Chrobák, CSc., University Hospital in Hradec Králové, $2^{\text {nd }}$ Department of Medicine, Division of Clinical Hematology, Sokolská 581, 50005 Hradec Králové, Czech Republic. e-mail: ladislavchrobak@seznam.cz 